\title{
Differences in decision-making criteria towards the return on marketing investment: A project business perspective
}

\author{
Hedley Smyth ${ }^{\mathrm{a}, 1}$, Laurence Lecoeuvre ${ }^{\mathrm{b}, *}$ \\ ${ }^{a}$ The Bartlett School of Construction and Project Management, University College London, 1-19 Torrington Place, London WC1E 7HB, United Kingdom \\ ${ }^{\mathrm{b}}$ Univ Lille Nord de France, LSMRC, Skema Business School, Avenue Willy Brandt, F59777 Euralille, France
}

Received 8 March 2013; received in revised form 6 January 2014; accepted 6 March 2014

\begin{abstract}
Assessing the value of marketing to a business remains a thorny issue in theory and practice. Decision-making at the finance-marketing interface is under-researched, particularly for project businesses. Confronted by demands of accountability concerning the allocation of resources to meet competitive pressures, the paper examines the quality and extent of dialogue in investment decision-making. The return on investment (ROI) and marketing-specific investment (ROMI) are important factors at the marketing-finance interface. ROMI/ROI is examined from quantitative and qualitative viewpoints. The empirical evidence shows that short-term financial criteria dominate and are misaligned to long-term performance of project businesses and business units. Marketing investment in relation to project markets poses a particularly challenging environment. Client lifetime value and programme data sets for ROMI coupled with qualitative decision-making offer ways forward with constructive dialogue at the finance-marketing interface. The paper concludes with detailed recommendations for research and practice.
\end{abstract}

(C) 2014 Elsevier Ltd. APM and IPMA. All rights reserved.

Keywords: Decision-making; Dialogue; Finance; Marketing; ROMI; Performance

\section{Introduction}

The value of marketing and the marketing function remains a thorny management issue in theory and practice. This is particularly the case from the perspective of financial management where exacting justifications are demanded from the marketing function to justify investment in marketing-related capabilities and activities (Srinivasan and Hanssens, 2009; Weissbrich et al., 2007). Marketing and finance are functions that are often treated in isolation both in research and practice. There has been no research at the marketing-finance interface in project businesses to address function and agency (cf. Jensen and Meckling, 1976). There are two dimensions that provide a starting point: the criteria of justification about investment decisions, and the extent of

\footnotetext{
* Corresponding author. Tel.: +33 32021 5985; fax: +33 320215959.

E-mail addresses: laurence.lecoeuvre@skema.edu (H. Smyth), h.smyth@ucl.ac.uk (L. Lecoeuvre).

${ }^{1}$ Tel.: +44 207679 5908; fax: +44 2079161887 .
}

alignment in the dialogue for decision-making at the marketingfinance interface.

The paper considers three levels in order to address the marketing-finance interface because each level exerts influence. There is the market and shareholder value, the level of the firm and finally the dynamics at the marketing-finance interface. Associated with these three levels are assessments on investment in and by firms, strategic decisions on budgeting, and the return on marketing-related and marketing-specific investment (ROI and ROMI). There is a gap in the literature concerning ROI and ROMI in theory and practice regarding the marketing-finance interface in sectors producing specific assets, particularly project businesses.

The aim is therefore to assess marketing-related and marketingspecific investments in terms of the justification criteria and the dialogue applied in decision-making. The project delivery channel comprises complex bundles of services and products, configured under conditions of uncertainty, and frequently engaging temporary and sometimes multi-organisational teams (e.g. Turner, 
2008; Winch, 2010). There are at least five evaluative objectives with associated outcomes in this context: i) ROI and ROMI are generally useful conceptual and appropriately applied practical tools; ii) ROI/ROMI is useful yet needs careful and considered application in specific contexts; iii) ROI/ROMI provides a basis yet more conceptual development is required for application across different types of project contexts, supported by an appropriate and shared dialogue; iv) some combination of the previous three outcomes; and v) ROMI/ROI is not useful.

The paper proceeds by reviewing the management literature in the investment market in relation to and for the firm, prior to analysing the application in project businesses. Focus is upon the justifications and dialogue used in decision-making around marketing investment and returns. Return on investment or ROI applies to all investment, which includes marketing-related invest- ment and ROMI applies to marketing-specific investment and marketing-related investment. Another perspective yields two types of investment: investment to improve the market position of the firm and ability to sell its service, and investments in the marketing function to improve performance, from which stance all such investment can be pejoratively categorised under ROMI. An overview of ROMI is provided, examining the concept from both quantitative and qualitative viewpoints. It then proceeds by reviewing ROMI against the concepts of the marketing mix and relationship marketing. The methodology and method are then presented as a springboard for the empirical investigation. The findings and discussion of the findings complete the main body of the work before concluding with statements upon the contribution to knowledge, the limitations and recommendations for both research and practice.

\section{Literature review in management and for project businesses}

Management is increasingly challenging the marketing function to demonstrate how marketing fits into financial metrics (Ganesan, 2012). This is partly driven by internal criteria concerning financial strategies of prevailing business models, and partly by the external drivers from investment markets that help shape prevailing business models. Marketing outcomes are therefore measured in terms of profitable contribution to shareholder value (Srivastava et al., 1998).

Investors are risk averse, being more concerned about potential losses than gains. Reconfiguring or increasing value propositions across a portfolio of customers may increase customer satisfaction, yet studies show that increasing customer satisfaction does not reduce supplier risk, although some recent evidence shows contrary results (Tuli and Bharadwaj, 2009). However, the marketing literature has shown that operational cost control as a major driver to improve returns works short-term, yet compromises long-term returns (Grönroos, 2000). A traditional production approach to cost accounting cannot be uncritically applied in service markets because cost reductions are a cut in investment. The service logic (Vargo and Lusch, 2004) takes matters a step further, questioning the production-service split and reinforcing the inseparability of costs and investment.

Project activities are located on the cusp of product and service. How project management is executed is service provision. Further, contracts, whether social through in-house provision or legally set out as in the open market, are agreed prior to all requirements being specified, and responses to emergent requirements form part of the service content. The capabilities required by project businesses support the customizing of complex and uncertain specific assets and the tailoring of services to context (Davies and Brady, 2000). This poses a challenge for investment in project business capabilities that are used to improve the service content and project specific investments. The latter are incorporated in the costs and any bid price. Technical and service capabilities developed at the business level are more contentious. These investments are marketing-related in order to implement the marketing strategy (Davies et al., 2007).

This provides the context in which project businesses allocate investments, taking into account a range of factors that influence the earning logic, profitability, and how this is perceived in relation to shareholder value. This in turn raises whether the finance drives or serves the firm (e.g. Grönroos, 2000; Srinivasan and Hanssens, 2009) whether as a production-cum-task or customer orientation, with short or long-term horizons for analysis and application in practice.

\subsection{The marketplace}

At the general market level are three related foci: (i) stocks, (ii) the firm or project business, and (iii) customers. Stocks concern the attractiveness for investing in firms and relate to shareholder value. The financial performance of firms feeds into shareholder value and is derived from the effects of marketing-related and marketing-specific investments on operational performance. Customers demand value for money (VFM) and can reasonably expect investment-derived improvement in VFM over time.

One of the greatest constraints on the development of effective governance and service provision has been impatient capital, whereby managers have sought to satisfy the demands of financial markets demanding low risk and high returns (Narayanan and DeFillippi, 2012). Shareholder value can be measured several ways using capital market-based measures, for example market to book ratio (Hogan et al., 2002) and the market value to the current replacement costs of its assets (Anderson et al., 2004; Tobin, 1969), which have less relevance the more the business is project-based because project businesses are heavily reliant upon the return on capital employed (ROCE) derived from accelerating the circulation of working capital. Therefore, measures such as market value added (MVA), which is the difference between the market value and capital employed (Griffith, 2004) are pertinent.

Finance managers take a summative perspective. Aggregated purchases or contracts give rise to the total profitability and market share (e.g. Reinartz et al., 2005). Declared profitability depends upon operational cost control, the amount reinvested for future 
growth and is moderated by policies towards dividend payments. Stock markets assess firms and their marketing investments for growth (profitability and/or market share) in terms of their portfolio. Portfolio management models have associated problems that take several forms. The most pertinent are: (a) marketing-related investment is not immediately visible to the investor, (b) short-term share price fluctuations obscure or tend to over-rule medium-to-long term effects of returns on marketing-related investments (Srinivasan and Hanssens, 2009), (c) successive marketing actions confuse payback predictions (Aaker and Jacobson, 1987), and (d) firms with high levels of product/service intangibility and market volatility typically leads to undervalued shares short-term compared to the long-run with consequences for the cost of capital and standing of the firm in the marketplace (Lev, 2004). Stock markets favour firms that focus upon value appropriation and dividend declaration above investment for value creation and future profit streams (Mizik and Jacobson, 2003). Investors are more risk-averse concerning losses than they are positive about the prospect of gains (Gupta et al., 2000; Tuli and Bharadwaj, 2009). In this way, finance managers are influenced by shareholder value.

\subsection{The level of the project business}

Financial management is concerned with maximizing resource use, hence minimizes costs and keeps investment at prudent levels. Projects are high risk and businesses carry serial risks across their portfolio. Therefore prudent levels are equated with minimal investment. Cost control determines the margin per unit of output (Ambler, 2005). Project cost control is conducted against in-house budgets or bid price, incorporating project-specific investments. In production these can be divided against constant units of output, yet projects are asset specific and have variable unit costs, so investment attribution is difficult. Capabilities also carry costs of further tailoring on a project-by-project basis (Davies and Brady, 2000). New project capabilities may have programme application, which is overlooked at portfolio level because calculations are based upon prior resource allocation (Lecoeuvre and Patel, 2009).

An analytical tool used to assess investments is the return on investment (ROI), which from a marketing perspective involves both marketing-related investments within ROI and the return on marketing-specific investment or ROMI (Lenskold, 2003). ROMI provides one comparative means and is expressed as:

ROMI $=\frac{\text { Gross margin }- \text { Marketing investment }}{\text { Marketing investment }}$

where the gross margin $=$ revenue - cost of goods - incremental expenses.

ROMI poses problems due to a lack of available aggregate data. Where data is available returns at operational and at a disaggregated level are typically below those at firm level (Manchanda et al., 2005), suggesting a) presentational categorization from an accountancy perspective, and b) earnings from other sources, particularly ROCE in project businesses through astute cashflow management. ROMI can be applied for types of or individual investment. This invokes the attribution problem, which is necessary to assess the strategic benefits of differentiation and competitive advantage (cf. Gruneberg and Ive, 2000). Rust et al. (2004) propose a broader conception to include return on quality, advertising, loyalty, and corporate citizenship. Rust et al. (2004) apply the following formula:

ROMI $=\frac{\text { Change in incremental customer equity (long-term discounted profit net of expenditure) }}{\text { Discounted expenditure }}$.

This adds to the attribution problem, whereby assessments can only be conducted at over the long run using aggregate data.

The marketing function has to justify investment proposals at board level. The marketing-finance issue is critical and the interface between the two exists at both a functional and agency level. The resource-based view of the firm strategically conceptualizes resource allocation to balance types of value creation and value appropriation (Barney, 1991; Wernerfelt, 1984). ROI and ROMI are applied in many firms, both retrospectively and to aid decision-making for new investments. Decisions are far from straightforward. Investments, especially for service provision, involve intangibility of processes, and issues of attribution of returns. Latitude and discretion in decision-making involve trade-offs because resources are scarce (cf. Mizik and Jacobson, 2003). Decision-making at the financemarketing interface is a function of complexity and ambiguity around resources in operational context, which for projects is problematic due to the absence of replicable actions and processes.

In mainstream production customers are unknown or treated in aggregate, hence the cost control focus. In projects the customer is known, either because it is commissioned in-house or in B2B markets. Approximately $80 \%$ of projects typically arise from $20 \%$ of the client base and repeat business is critical. Securing repeat business depends upon consistently delivering the customized technical content and tailored services as part of customer management (Smyth and Fitch, 2009). This brings customer or client lifetime value (CLV) into focus, where:

CLV $=$ Value of client programme $\times$ Rate of being shortlisted $\times$ Strike rate of winning where the value of client programme $=$ estimated value over lifetime of the retained client, say 10 years.

The total CLV across all key customers makes a significant contribution to profit. Investment is needed to (i) maintain patterns of repeat business, and (ii) to improve retention rates. CLV is frequently overlooked in project businesses by investors, hence at the 
finance-marketing interface, although it is selectively used among project businesses (Smyth and Fitch, 2009). This is an important factor towards accurate share valuation and the re-rating of undervalued firms on stock markets (Lev, 2004). At the level of the firm, ROI, ROMI and CLV feed into accounting-based measures in regard to serving shareholder value, however, profitability varies extensively between customers (Storbacka and Nenonen, 2009). This suggests that disaggregation is needed, in particular for key clients. Eggert et al. (2006) point out that the focus of marketing metrics is shifting from aggregated measures like market share, profit, and sales, towards performance indicators at the dyadic level: relationship performance. This links to CLV and a disaggregated approach to ROI and ROMI specifically. Decision-making at the finance-marketing interface looks different where investments are considered in relation to CLV and supplier programmes rather than the project level alone. The repeat business motive links CLV to the project level and depends upon three factors:

1. Frequency of business opportunities in client programmes of work (Chambers et al., 2009; Smyth and Fitch, 2009; Winch, 2010);

2. Frequency of repeat work or type of output (Artto et al., 2011; Davies and Brady, 2000; Whitley, 2006);

3. Frequency with which the same supply cluster or supply chain members can be used (Pryke, 2012).

The disaggregated level raises the types of investment, that is, marketing-related in the form of general organisational capabilities (Davies and Brady, 2000), marketing-specific capabilities (Möller, 2006) and project capabilities (Brady and Davies, 2004).

\subsection{The level of functional interfaces}

Reinartz et al. (2005) argue that optimal profitability coincides with optimal return on investment. Ambler (2005) concluded that the maximum ROI is reached with lower expenditure rather than pursuit of maximum profitability. Yet, timescales of assessment are significant (Mac, 2007). Efficiency assessments are in tension with marketing, which is also an effectiveness function. Cooperation between marketing, finance and other operations, such as procurement for supply chain management and project management during execution, the marketing-finance interface is of generic importance at both an operational level and for decision-making (Ganesan, 2012). Yet marketing and finance frequently apply different methods, timescales and measures in making assessments.

Finance tends to give primacy to short-term efficiency measures and quantitative methods. Marketing tends to give primacy to, long-term effectiveness measures and qualitative methods (Webster et al., 2005): "value creation is the cornerstone of marketing" (Mizik and Jacobson, 2003: 63). A dialogue is needed to bridge the gap (Ballantyne and Varey, 2006), which engages with agency at the finance-marketing interface. Function and agency come together as follows: "The marketing profession is being challenged to assess and communicate the value created by its actions on shareholder value ...chief executives and board directors are more often disappointed in the performance of their chief marketing officers than in that of the other senior executives in the firm" (Srinivasan and Hanssens, 2009: 293).

Effectiveness also feeds efficiency. Research demonstrates a strong relationship between capability development that creates value and financial performance (Capon et al., 1990; Mizik and Jacobson, 2003), leading to higher levels of customer satisfaction and lower marketplace risk (Tuli and Bharadwaj, 2009), in turn affecting the rating of stocks (Hong and Sarkar, 2007; Lui et al., 2007). Marketing-related investments are typically cross-functional bundled resources, especially from the perspectives of relationship marketing (Grönroos, 2000) and the service-dominant logic (Vargo and Lusch, 2004). However, the marketingfinance interface exhibits a dialogue of conflict based upon a predominantly transactional perspective. Tuli et al. (2012) argue that senior management signals their approach, hence the criteria applied in decision-making.

Kimbrough and McAlister (2009) argue that there is a need for more investigation at the finance-marketing interface. Gupta and Zeithaml (2006) argue for more research linking marketing metrics with firm performance. Weissbrich et al. (2007) found the need for an "integrative framework", identifying three categories of study. The finance-marketing interface characteristics focus upon exchange and communication, budgeting, pricing, marketing performance measurement, reporting, problem solving, and cultural differences; the antecedents of the marketing-finance interface, focusing upon the attitudes to dependence, procedural fairness and inter-functional rivalry; and performance implications are examined through relationships, decision-making and effectiveness through relationship and reputational value. They proposed a five-layer conceptualisation of the interface (see Fig. 1), covering information sharing around intelligence and knowledge sharing, structural linkage through formal channels and interactions, power distribution between the two disciplines, orientation of individual functions including goals and time horizons, and knowledge of individual functions and expertise. The constructs refer to the lack of dialogue and mutual understanding that affects business performance (Weissbrich et al., 2007). Calls for closer collaboration between finance and marketing are not new (e.g. Ganesan, 2012; Wierenga, 2011; Zeithaml et al., 2006). Finance and marketing require two overall things to address the differences: a dialogue (cf. Ballantyne and Varey, 2006), from which complementary methods for firm performance and investment assessment, ROMI acting as one starting point (Farris et al., 2006; Lenskold, 2003). 


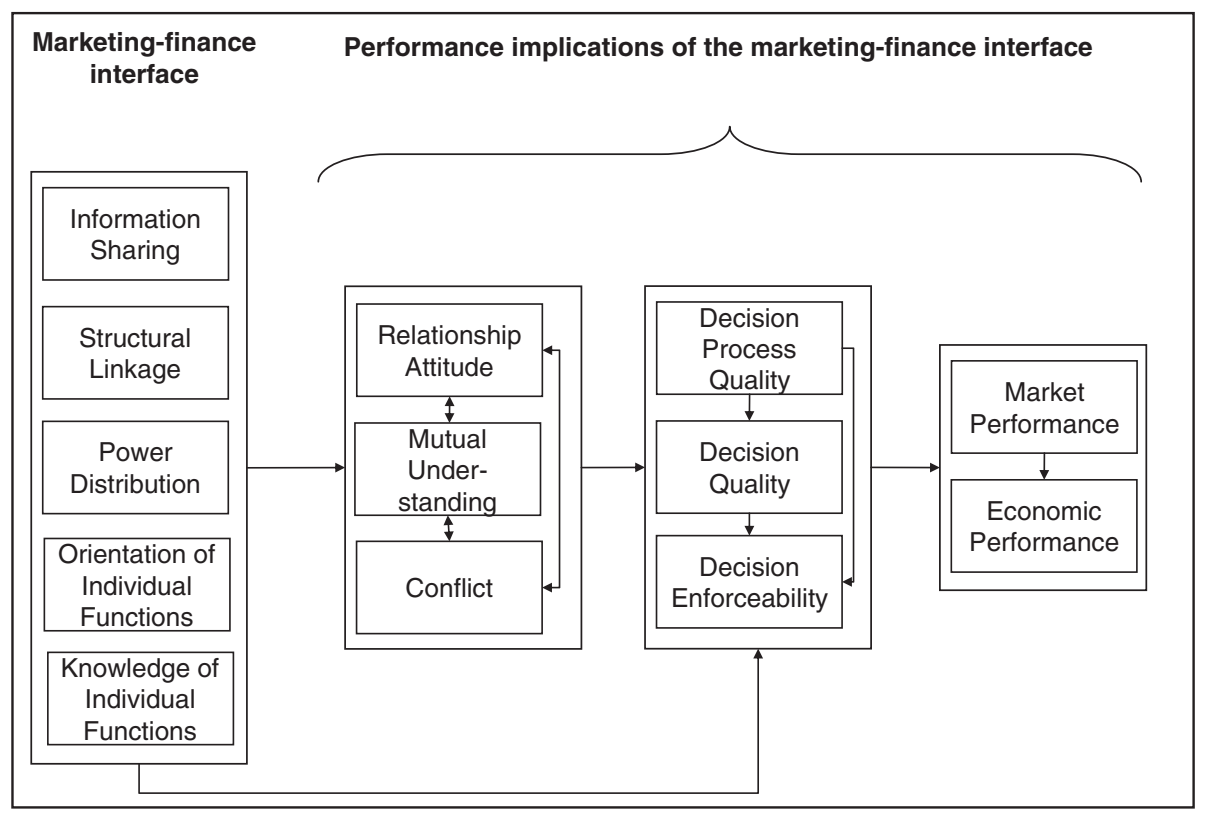

Fig. 1. Integrative framework of the marketing-finance interface and its performance implications.

The functional interface and agency to articulate the interface are influenced by qualitative and quantitative approaches. These are briefly reviewed in the light of the foregoing issues.

\subsubsection{The quantitative approach to ROMI}

The quantitative approach is based upon looking at the results from investment inputs compared to profit outputs. Low expenditure is coupled with high profitability (Ambler, 2005), yet this does not automatically lead to low investment. Effective investment is also needed, which is evident in long-run aggregated data. ROMI calculations are useful for disaggregated investment too, for example linked to CLV. Long-run quantitative data has two decision-making purposes. First, prioritizing activities (Bourdreault, 2004; Powell, 2002) is informed by past trends, setting investment against growth rates and market share. The second purpose is to address financial pressure experienced by marketers (cf. Weissbrich et al., 2007), to evaluate investment in segments or programmes, for capability development and key customers. Both purposes provide a shared quantitative basis for the marketing-finance dialogue, and help to define the balance between resources and customer profitability using ROI/ROMI (Batteau and Changeur, 2006; Reinartz et al., 2005). In businesses where projects are sourced in-house, for example for new product development (NPD), ROMI calculations can be conducted for NPD activity or combined with R\&D investment. There is reasonable opportunity to defray costs against future units of output. Outsourced projects cannot be treated this way. Being highly variable in size and complexity, for example Private Finance Initiative/Public Private Partnership (PFI/PPP) IT projects for government departments, the project-specific resource commitments render statistical analysis of little use. Risk management at the project level will tend to dominate agency thinking in financial management where long-run data is absent. However, both internal and externally sourced projects need setting in the context of long-run data for effective decision-making.

Finance and marketing share the same stakes and sometimes the same relational networks (de Ruyter and Wetzels, 2000), yet the disciplines and language are different. Where long-run quantitative data is unavailable, a dialogue is needed (Ballantyne and Varey, 2006; Warnier et al., 2004).

\subsubsection{The qualitative approach}

The qualitative approach is based upon looking at the results from investment inputs compared to returns. The principle is to use ROMI as guidance alongside other qualitative data to analyse and perform judgements that are interpretative and often based upon heuristics (e.g. Kahneman and Tversky, 2000). This takes inputs and outputs together because distinct patterns seldom arise for either factor. Inputs relate to the unevenness of demand and capability development (Davies et al., 2007) and responses to specific complex projects. Project inputs are individually shaped during prequalification and bid management (e.g. Cova and Salle, 2011). On the output side, margins are of limited use in most project markets (Gruneberg and Ive, 2000), for example the percentage mark up on projects is low and sometimes negative for survival reasons during economic downturns (Skitmore and Smyth, 2007). Final accounts and gross margins are subject to long time lags. The qualitative approach therefore faces challenges for managers in the dialogue. 
Financial management can focus upon capabilities to improve the return on capital employed (ROCE). Marketing can focus upon investment to improve CLV. Grönroos (2000) brought forward several measures, the most pertinent to project markets probably being:

CLV $=$ Transaction value $+/-$ Relationship value

$\mathrm{CLV}=\frac{\text { Long-term revenue }- \text { Generation support }}{\text { Price }+ \text { Relationship costs }}$.

The CLV approach reported by Smyth and Fitch (2009) used a price earnings ratio for the service being offered applied to customer margins. The international contractor therefore applied CLV to its customer relationships to assess the value being added to the business. Customers are ranked upon expected future value of the earnings. Value is derived using a simple price earnings ratio $(\mathrm{P} / \mathrm{E}$ ratio) quoted in accounts or reported on stock markets, for example pre-2008 pure construction companies were valued at 7 times net earnings, services companies (FM) at 15 times net earnings, management at 10, engineering at 15, international at 7 and financial companies at 12. Earnings from customers are disaggregated by these service offerings and then the appropriate P/E ratio is applied. The ratings are not project-based, but CLV-based (Smyth and Fitch, 2009). Drawing upon these types of assessments and applying to CLV in the project context, the following moderation is generated:

$\mathrm{ROMI}=\frac{\text { Programme revenue }- \text { Relationship and capability development }}{\text { Transaction program value }+ \text { Non-recoverable relationship costs }}$.

Non-recoverable relationship costs are those that add value to the customer in service and content. They are excluded from project budgets and are carried at programme and/or client management level of the project business. Cost recovery is programme related through growth and market share. In terms of the relationship of CLV to ROMI, the following expression may be used:

$\mathrm{ROMI}=\frac{\text { Gross programme margin }- \text { Marketing investment }}{\text { Marketing investment }}$

where the programme relates to the programme for the client.

The calculative outputs for ROMI should be used as indicative under qualitative assessments, thus feeding into a dialogue around shared understanding at portfolio and programme levels. The CLV approach can be used for key customers across the supplier portfolio, for particular segments and programmes.

Certain procurement routes in particular segments can have positive effects, for example governments use PFI/PPP for many projects from IT to infrastructure to reduce capital commitments in favour of payment through revenue streams. The profit margin on delivering infrastructure could typically be in the region of 3\%, whilst the equity stake in the project for the contractor may produce a $14 \%$ ROI. Such returns must take into account the substantial bidding costs for the concession. Some bidding costs are defrayed through a high strike rate through governments negotiating with preferred bidders. PFI/PPP projects tend to exacerbate the levels of uncertainty and "lumpiness" of the market that render the qualitative approach to ROMI most pertinent.

The value of ROMI depends upon more than the quantitative and qualitative approaches. It is also contingent upon the selected marketing approach. Two paradigms are briefly reviewed on the basis of the issues raised, namely the transactional marketing mix approach and the relationship marketing approach that includes project marketing.

\subsubsection{ROMI and the marketing mix}

ROMI has the potential to secure a balance of ingredients under the marketing mix (cf. Borden, 1964) that is determined by capabilities around the so-called 4Ps and subsequent variants (McCarthy, 1964). The underlying assumption is that markets and any particular exchange process are largely homogeneous and so investments are the primary variant to establish the precise mix of ingredients. This relates closely to the quantitative approach for several reasons:

1. Data is easier to collate and aggregate for analysing investment decisions.

2. The calculative process over the short and long-term shows changes in the mix of the ingredients, having implications for resource allocation and margins, the highest ROMI helping assess the best strategy.

Yet project markets are heterogeneous and contracts are incomplete, transactions being subject to measurement and claims for the work done. Final accounts do not relate to bid prices. Further, functionaries are task-focused according to expertise (Handy, 1997) rather than customer or marketing focused, hence value propositions may be misaligned with customer expectations. Consequently ROMI depends upon aggregated data that is both limited in availability short-term and has limited application at the project level. Transactional practice is conceptually misaligned in project markets (e.g. Cova et al., 2002; Smyth, 2000). Alignment is improved through systems integration (Davies et al., 2007) supported by relationship development in the project context or milieu (Cova et al., 2002). 


\subsubsection{ROMI and relationship marketing}

ROMI has the potential to support investment in relationship marketing, conceiving the exchange process as constituting an episode that is part of serial interactions where in-depth understanding of customer needs is solicited and is part of seeking repeat business over the CLV (e.g. Grönroos, 2000). A long-term view is needed, with the customer as the unit of analysis as well as the project where greater homogeneity and consistency is present. CLV provides a long-term basis for decision-making, carried out for key customers and programmes. At a detailed level, new resource commitments to add service and technical value are investments (Lay et al., 2009) to lever value and reduce execution costs.

Relationship marketing aims to increase repeat business to improve CLV and grow market share. The initial costs of may increase hence reducing the ROMI figure. Similarly, project marketing has arisen from relationship marketing (e.g. Cova et al., 2002; Hadjikhani, 1996) to shape projects that develop win-strategies that match customer requirements (e.g. Cova and Salle, 2011; Cova et al., 2002), and, manage discontinuity and uniqueness as well as the complexity characteristics of project markets (Skaates and Tikkanen, 2003; Skaates et al., 2002). Lecoeuvre-Soudain and Deshayes (2006) have developed a three-stage project marketing phasing (Cova and Hoskins, 1997) into four phases: pre-project marketing, marketing at the start of the project, ongoing project marketing, and marketing intended to create the conditions of future projects that span the period of sleeping relationships in which there are no projects being brought forward from the pipeline towards the execution pipeline (Skaates and Tikkanen, 2003). Project shaping emphasises the differentiation of content and resource mobilization, adding to the problematic nature of ROMI for individual projects, yet endorsing the long-term role as a management tool within project marketing. In other words, relationship and project marketing recognise, indeed increase the need to include CLV — see Eq. (7) above.

\section{Methodology and methods}

The research aim is to investigate the appropriateness of ROMI to establish a basis for applying ROMI, and induce a shared dialogue to facilitate decision-making at the financemarketing interface. There were five research objectives stated in the Introduction, which are converted into research questions. How these arose in broad terms from the literature reviewed is set out in Table 1.
Research claims that there is a strong relationship between capability development and financial performance (Capon et al., 1990; Mizik and Jacobson, 2003). Gupta and Zeithaml (2006) argue for more research linking marketing metrics with firm performance. To date scant research exists to fill this gap and none for project businesses. We propose to look at preliminary results secured through qualitative research conducted through interviews and observation. This qualitative research permits greater understanding of the specificities of the marketing-finance interface,

Table 1

Mapping the literature and research questions.

Issues identified in the literature

Research questions

Marketing and marketing-related investments to improve performance and delivery capital versus impatient capital amongst shareholders demanding low risk and high returns (Narayanan and DeFillippi, 2012).

Application embodies efficiency and effectiveness criteria (e.g. Mizik and Jacobson, 2003), which lead to issues around the next research question.

Investment to add customer value does not reduce risk to the supplier (Tuli and Bharadwaj, 2009).

Operational cost control in service provision tends to compromise value (Grönroos, 2000).

Context concerns decision-making around investment and operations (Ganesan, 2012), especially value creation to yield returns.

Finance and marketing as functions are mediated through agency, which includes awareness, language and interaction in dialogue and decision-making (e.g. Ballantyne and Varey, 2006; Kimbrough and McAlister, 2009).

Attribution issues, exacerbated by the intangibility of investment and returns in the short term. Returns at operational levels are typically below those at firm level (Manchanda et al., 2005).

An integrative approach is needed (e.g. Weissbrich et al., 2007).

ROI and ROMI in the context of CLV (Smyth and Fitch, 2009).

There are limits to the application of a quantitative approach in project businesses and limits to the application of the marketing mix (e.g. Cova et al., 2002).

Marketing and marketing related investment is only useful where related to performance

(e.g. Gupta and Zeithaml, 2006).

Impatient capital (Narayanan and DeFillippi, 2012) challenges investment, and emphasising operational cost control, value appropriation and dividend declaration (Mizik and Jacobson, 2003).

Incentivized pay packages of senior management are frequently linked to performance of share

value. Poor short-term share performance can be viewed as the failure of management

(Srinivasan and Hanssens, 2009). This constrains investment. i). To what extent is ROMI/ROI generally a useful conceptual and appropriately applied practical tool?

ii). To what extent is ROI/ROMI a useful tool yet needs considered application regarding context?

iii). To what extent does ROI/ROMI provide a basis yet more conceptual development is required for application across different types of project contexts, supported by an appropriate and shared dialogue? iv). To what extent is a combination of above appropriate for ROI/ROMI?

v). To what extent is ROMI/ROI not useful? 
and the level engagement at this interface. It also addresses the view of managers concerning ROMI as a tool to aid constructive dialogue and decision-making.

The methodology is interpretative (Miles and Huberman, 2003; Yin, 2009), permitting preliminary evaluation of the marketingfinance interface and of the role of ROMI. The method is characterized by progressive and iterative construction, applying constant backward and forward evaluation between the empirical and theoretical. Listening to actors and respondents and gauging their level of interest at the marketing-finance interface were important for soliciting information (Garand and NkonngoloBakenda, 1996). Personal contact as a vehicle for sensemaking (Weick, 1995) is very important to enter the universe of people's construction of "their world" formed part of the conduct for the research. This is particularly important for this research paper that arose from a broader study, indeed, the topic arose from empirical investigation rather than the research being set up to examine it.

The methodology is therefore inductive, allowing the actors to discuss the issues that they believe are important. This is for two reasons. The first reason is that issues raised reflect their thinking, which is likely to inform management discussion and consequently influence subsequent action. The second reason is that the study originally had another research agenda, yet, the issues raised in interviews conducted for that research kept alluding to and directly raising the issues discussed in this paper. Thus the research aim and objectives set out above can be viewed as inductively derived too. Indeed, this serves to add weight to the importance of this research, for the agenda was not set in advance but from those interviewed. Therefore the issues were not prompted by direct research questions on the finance-marketing interface, ROMI/ROI and CLV. Making sense of the practical issues raised required some interpretation, which in part has been provided through the literature review, and which did not so much generate the research objectives as make sense of the issues derived from a set of interviews.

Project business units were selected as part of large companies as these units are thought to be more likely to apply ROMI than pure project businesses. The companies were all amongst the market leaders in their sector (e.g. LVMH, PSA, Credit Lyonnais, Danone, Disneyland, Ferrero, Orange, Renault). They have marketing budgets and the majority have dedicated marketing teams. Interviews were conducted over 6 months with the President, General Manager, Marketing Director, Director of Communications and marketing team members responsible for projects such as new product launches, market development, and communication plans (Table 2). Confidentiality reasons as demanded by respondents restrict saying more about those interviewed and it is the patterns that derived from the sample that are germane to this research rather than individual case companies.

Non-directive and semi-directive interviews were conducted, generally lasting 45-90 min, the maximum being $2 \mathrm{~h}$. Certain respondents were interviewed twice - a total of 87 interviews being undertaken. The method corresponds to exploratory objectives, allowing "intelligibility" derived from the evaluation of data and meanings to piece together a picture a type of "puzzle" pieced together through several stages of content analysis in a rigorous and coherent way to achieve an
Table 2

Schedule of companies and interviews.

\begin{tabular}{|c|c|c|}
\hline $\begin{array}{l}\text { Company } \\
\text { with project } \\
\text { business unit }\end{array}$ & Function of respondents & $\begin{array}{l}\text { Number o } \\
\text { interviews }\end{array}$ \\
\hline A & General Manager; Marketing Director & 3 \\
\hline B & President; Marketing Director & 4 \\
\hline $\mathrm{C}$ & $\begin{array}{l}2 \text { Team Members; Marketing Director; } \\
\text { Director of Communication }\end{array}$ & 5 \\
\hline $\mathrm{D}$ & $\begin{array}{l}\text { General Manager; Marketing Director; } \\
3 \text { Team Members }\end{array}$ & 5 \\
\hline $\mathrm{E}$ & $\begin{array}{l}\text { President; Director of communication; } \\
\text { Marketing Director; Team Member }\end{array}$ & 4 \\
\hline $\mathrm{F}$ & $\begin{array}{l}\text { General Manager; Marketing Director; } \\
\text { Director of Communication }\end{array}$ & 4 \\
\hline $\mathrm{F}$ & Marketing Director; 3 Team Members & 4 \\
\hline $\mathrm{H}$ & $\begin{array}{l}\text { President; Director of Communication; } \\
2 \text { Team Members }\end{array}$ & 5 \\
\hline I & President; General Manager; Director of Marketing & 3 \\
\hline $\mathrm{J}$ & $\begin{array}{l}\text { President; General Director; Marketing Director; } \\
\text { Director of Communications }\end{array}$ & 5 \\
\hline K & General Director; 3 Team Members & 4 \\
\hline $\mathrm{L}$ & $\begin{array}{l}\text { President; General Director; } \\
\text { Director of Communications; Team Member }\end{array}$ & 4 \\
\hline M & $\begin{array}{l}\text { President; General Director; Marketing Director; } \\
\text { Director of Communications }\end{array}$ & 5 \\
\hline $\mathrm{N}$ & $\begin{array}{l}\text { General Director; Marketing Director; } \\
3 \text { Team Members }\end{array}$ & 7 \\
\hline $\mathrm{O}$ & $\begin{array}{l}\text { Marketing Director, Director of Communications; } \\
2 \text { Team Members }\end{array}$ & 4 \\
\hline $\mathrm{P}$ & $\begin{array}{l}\text { General Director, Marketing Director, } \\
\text { Director of Communications }\end{array}$ & 4 \\
\hline Q & Director of Communications; 3 Team Members & 4 \\
\hline $\mathrm{R}$ & Marketing Director; Director of Communications & 4 \\
\hline $\mathrm{S}$ & Director of Communications; 2 Team Members & 3 \\
\hline $\mathrm{T}$ & Marketing Director; 3 Team Members & 5 \\
\hline
\end{tabular}

exploratory resolution. Analysis of documents, direct observation (in situ) was employed (Groleau, 2003) to describe individual, collective and organisational cognitive processes to establish the extent of organisational reliability (Journé, 2005; Weick, 1995). Patterns are identified in the results that have wider implications, albeit not on a mechanistic basis because of context specificity. Confidentiality reasons as demanded by respondents restrict saying more about the detailed content and attribution of information provided and quotes cited to particular actors, yet are unnecessary to establish contingent patterns of outcome to fulfil the aim and objectives identified.

The method employed to interpret the interview information was an iterative one of reading over the findings, making notes and classifying (cf. coding) significant issues that repeatedly arose until saturation was reached.

\section{Findings}

A consistent approach to managing the marketing-finance interface and for the application of ROMI was absent. The overall picture was variable, typically partial with a mix of practices that aligned with good practice and partial practice that was not working on its own terms for decision-makers. Where ROMI was employed it was not used at programme or client level, even where the client was in-house. CLV was absent in consideration. A 
Table 3

Decision-maker evidence and the research issues.

\begin{tabular}{|c|c|c|}
\hline Research questions & Concepts for coding and categorization & Quotations from key decision-makers \\
\hline $\begin{array}{l}\text { i). To what extent is ROMI/ROI } \\
\text { generally a useful conceptual } \\
\text { and appropriately applied } \\
\text { practical tool? }\end{array}$ & $\begin{array}{l}\text { Investments in performance v. impatient capital } \\
\text { Efficiency and effectiveness criteria applied } \\
\text { Financial drivers in decision-making } \\
\text { Role of other drivers in firm and service performance } \\
\text { ROMI/ROI application }\end{array}$ & $\begin{array}{l}\text { 1. We are more and more driven by financial } \\
\text { considerations. ...we have toggled into a financial culture. } \\
\text { 2. [ROMI is] a model that leads us to ask questions. } \\
\text { 3. [ROMI is] can help teams to sell their investment. }\end{array}$ \\
\hline $\begin{array}{l}\text { ii). To what extent is ROI/ROMI a } \\
\text { useful tool yet needs considered } \\
\text { application regarding context? }\end{array}$ & $\begin{array}{l}\text { Financial drivers in decision-making } \\
\text { Risk reduction } \\
\text { Attribution of returns } \\
\text { Degree of shared dialogue }\end{array}$ & 4. Show me where is the pay-back is. \\
\hline $\begin{array}{l}\text { iii). To what extent does ROI/ROMI } \\
\text { provide a basis yet more conceptual } \\
\text { development is required for } \\
\text { application across different types of } \\
\text { project contexts, supported by an } \\
\text { appropriate and shared dialogue. }\end{array}$ & $\begin{array}{l}\text { Short-term performance serving financial markets } \\
\text { and management v. serving clients } \\
\text { Attribution of returns } \\
\text { Degree of shared dialogue } \\
\text { Effectiveness and CLV }\end{array}$ & $\begin{array}{l}\text { 5. The pressure of short-term performance ...leads } \\
\text { to some innovative solutions. } \\
\text { 6. Are we investing enough for our new products? } \\
\text { 7. Everyone knows where the priorities are. } \\
\text { 8. It's a mess... We are lost, and cannot interpret } \\
\text { what is going on. }\end{array}$ \\
\hline $\begin{array}{l}\text { iv). To what extent is a combination of } \\
\text { above appropriate for ROI/ROMI? }\end{array}$ & $\begin{array}{l}\text { Integration } \\
\text { Shared understanding and dialogue }\end{array}$ & $\begin{array}{l}\text { 9. One of the most important parts is the annual } \\
\text { business plan. }\end{array}$ \\
\hline v). To what extent is ROMI/ROI not useful? & $\begin{array}{l}\text { Investments in performance v. impatient capital } \\
\text { Scarce resources } \\
\text { Heuristics in decision-making } \\
\text { Financial drivers in decision-making } \\
\text { Risk reduction } \\
\text { Attribution of returns } \\
\text { Degree of shared dialogue }\end{array}$ & $\begin{array}{l}\text { 10. [For budgeting and tools of assessment] you make } \\
\text { do with what you have... } \\
\text { 11. There is poor application of ROMI in marketing } \\
\text { because resource allocation is imprecise. } \\
\text { 12. Marketing teams are at sea; they are floundering. } \\
\text { 13. [Experience shows] if it has already worked, } \\
\text { there are good reasons. } \\
\text { 14. I want that someone to show me that it } \\
\text { [marketing-related investment] delivers added value. } \\
\text { 15. How can ROMI be integrated in day-to-day work? }\end{array}$ \\
\hline
\end{tabular}

consistent pattern was most evident amongst those commenting from a financial perspective, reflecting short-term drivers of efficiency to maximize returns regardless of client or long-term criteria. Some specific evidence is presented in Table 3, linking the key research question and concepts from the review derived from Table 2 with a series of quotations from the key decision-makers interviewed. The quotations are presented as succinct comments that reflected themes and issues raised by others interviewed.

Concerning ROMI, it was found that specific tools with a ROMI orientation were developed in accordance with internal processes to provide performance indicators amongst a minority of project business units. The majority of respondents stated that ROMI is complex and difficult to interpret in practice, the basic formula being inapplicable (see Table 3). Respondents preferred multi-data models, combining quantitative and qualitative approaches. The respondents used multi-data models for simple and multiple regression analysis for estimation and simulation purposes despite statistical limitations, hence paucity of results for informing a dialogue and decision-making. A few respondents applied other ROMI tools. The joint solution of MMA "ROI evaluation" and Copernicus to help marketers evaluate potential investment, and the "Microsoft Office Excel 2003 templates" of DemandROMI were selectively applied. In general, budget planning and decision-making were informed by the last experiment and by extrapolating the experience amongst the decision-makers, derived from past practice in the firm and responses to competitor actions.

ROMI was applied a posteriori, consequently limiting consolidation of indicators for financiers to establish forecasts under short-term assessments (e.g. Quotes 1, 9 and 10, Table 3). The influence of financial auditors was used in dialogue at marketing department meetings to transfer responsibility from the finance department to marketing hence limit investment. Finance largely drove business decisions around efficiency measures, rather than serving and guiding business towards effective financial performance in relation to marketing and probably other functions too.

The power of financial departments forces marketing to justify their recommendations of investment with great rigour. The logic of rigour demanded by accounting practice did necessarily accord with the type of rigour for realistic assessment (see Quote 10; cf. Quote 2). The finance-marketing interface was characterized more by finance controlling inputs and cost efficiency, whilst marketing focused upon outputs and performance outcomes (e.g. Quotes 6 and 7). This demonstrated a lack of shared dialogue. Qualitative factors and heuristics were important yet were secondary in decision-making. The respondents all recommended a "real management" of the marketing-finance interface. Drilling down to a finer grain of analysis, in the majority of companies the marketing departments presented ROMI/ROI calculations to justify their investment recommendations. The analysis of all the interview findings clearly shows that marketers have increasingly had to 'prove' the probability of short-term profitability to support investment plans, (Quotes 4; cf. 14) in order to maintain "influence" within their companies and for the project business units.

Justifications not only involve calculating budgets and splitting them into the different actions, but also involve simulating 
investment returns at adequate or above average margins. Tools used were company specific, having ROMI orientations without necessarily following established procedures for calculations. For example, when a company decides to create a programme of fidelity, profit stream predictions over a defined period were made with mechanisms to optimize profitability in the short and medium terms, which were then integrated into other performance indicators. Establishing realistic assumptions depended on company and sector skills, strategies, product types and resources. There was more concern to choose assumptions that supported the functional remit rather than facilitating a finance-marketing dialogue to aid decision-making (see Quotes 11-15; cf. 6-8). Those interviewed considered ROMI a useful aid that is "close to reality", but only when some critical contextual factors can be isolated - perspectives illustrated by different respondents (Quotes 2-7). This is both a general management and project business problem.

The findings show that executive board members prefer a holistic, more 'global' and integrated approach to information, yet prefer an atomistic and functional view to decision-making, especially regarding resource and return attribution. Further, some respondents quoted the integrated marketing communication used by advertisers, as an example, which can combine qualitative with quantitative approaches. Several respondents doubted the capacity of their company to use an integrated approach. Qualitative use of ROMI was patchy and inconsistent. Ultimately many decisions were largely based upon quantitative data, yet intuitive objections to marketing investment coming from financial managers in the absence of attributable quantitative data (see Quotes 4 and 13). Respondents repeatedly stated that ROMI has to be used with reference to recent experience and the last experiment, a functionalist approach that tends to reinforce the status quo rather than facilitate a constructive dialogue for decision-making. The power and influence of finance tend to overrule dialogue and balanced decision-making. Financial issues were recognised as dominating decision-making by the large majority interviewed. Some respondents evoked finance as the cultural context, that is, firms' shared values and underlying assumptions that render it difficult to justify proposals or challenge decisions (Quote 1).

Finally, the rise of "financial power" may force marketing departments to increasingly justify their plans and recommendations for investment with greater rigour. All recommended a management "rapprochement" between finance and marketing, yet admit to not knowing how to concretely implement this management interface and how to develop coherent cross-functional dialogue (Quote 3; cf. 8 and 12). Marketers know that they must articulate the marketing-finance interface; "they will not have the choice". Whilst ROMI made a contribution towards facilitating a dialogue on occasions, it was not decisive and dialogue was conducted upon misaligned criteria in decision-making.

\section{Discussion and perspectives}

It has been claimed there is a need for a dialogue at the marketing-finance interface to facilitate decision-making (cf. Ballantyne and Varey, 2006). Marketers are under considerable financial pressure to justify their role and actions (Weissbrich et al., 2007), specifically justify investment proposals (Srinivasan and Hanssens, 2009). ROMI has been investigated as a tool to aid dialogue and decision-making at the finance-marketing interface. The review of the literature developed the argument for a qualitative approach based upon a long-term focus, augmented by quantitative data on CLV and supplier programmes or customers and their contribution to financial performance from a marketing perspective (cf. Rust et al., 2004).

Financial management was found to be increasingly dominant and cost focused in the review (e.g. Ambler, 2005). Although the overall intent was for a holistic and integrated approach, the evidence showed a fragmented functional approach to decisionmaking that was dominated by financial criteria based upon short-term returns and cost control. Finance preferred intuition in preference to financial measures when it seemed to suit short-term cost control criteria, even where this militated against possible long-term shareholder value. There was limited or no shared dialogue across the cases. The traditional production dominated financial thinking (cf. Grönroos, 2000) at the exclusion of effectiveness and project returns over-shadowed CLV and programme considerations, probably to the detriment of long-term performance and shareholder value (Weissbrich et al., 2007). The literature review analysis is mapped against the main findings from a preliminary exploration of the marketing-finance interface and the application of ROMI (Fig. 1).

The review found ROMI to be a useful conceptual tool at the marketing-finance interface. This was not borne out in practice. This was partly due to the context specific development of ROMI-type tools, but mainly due to the lack of consistent application of ROMI and for long-term contribution to financial performance. Application did not encompass a holistic view nor provide a canonical model. Finance forestalled dialogue and dominated decision criteria, using a posteriori rationalization based on statistically weak and scant short-term data. Further finance tended to place responsibility upon the marketing function to provide quantitative data to demonstrated added value and high returns on investment, yet failed to collect data, such as CLV and programme data over longer periods that is available and reliable for purposes of attribution.

In sum, the review shows ROMI to be useful, especially where supported by CLV and other qualitative data. The evidence found a gap between this research objective and the evidence. It was found that:

- ROMI/ROI is not useful short-term and on a project specific basis - see Research Questions i) and v),

- ROMI/ROI is useful for long-term CLV and programme contexts in ways that take account of the specific assets, B2B and service contexts - see Research Questions ii) and iv).

- ROMI/ROI is not currently useful as practiced because there is a misalignment of criteria for dialogue and in decision-making - Research Question v).

- It is unclear as to whether further conceptual development is needed as there is insufficient appropriate application of ROMI/ROI to assess shortfalls, but it is probable that further refinement is needed in the project context and possible that substantial development is needed - Research Question iii). 
Overall, a constructive dialogue is needed. Whilst finance managers are placing more emphasis upon the marketing function to justify investment, finance is failing to take responsibility for the project context and collect appropriate data to support marketing. There may be wider implications across other asset specific markets allowing for 'translation' into context. The evidence and discussion suggest that a general or universal model of ROMI is illusory.

In sum, it was found that ROMI was of limited use in practice. The conceptual promise derived from the literature remains unfulfilled. The jury is still out as to its use in practice as finance was found to be dominant in decision-making, and the extent to which ROMI/ROI needs further conceptual development remains unanswered. ROMI retains a basis to help facilitate a dialogue, yet the finance function appears unwilling to concede power in favour of constructive dialogue. This discussion point may have wider consequences than project businesses.

Demands of the market and in society have and will continue to increase. The internal need for a dialogue is increasing in parallel. Therefore a range of perspectives in research and an increasing expectation from managers for advice and guidance is emerging. The model brought forward by Weissbrich et al. (2007: see Appendix) provides preliminary pointers on integration; a "dual or double" mutual "knowledge of individual functions" to be held at the marketing-finance interface. This may help yet is insufficient to improve interface management because other functions may share similar issues, such as human resources.

The exploration has helped conclude that ROMI/ROI retains potential, especially as a long-term quantitative-cum-qualitative tool to measure the economic benefits created by marketing investments. The practice of applying ROMI-type tools on a short-term basis to prioritize marketing investments on a 'scientific basis' is unfounded as a robust approach from the evidence.

\section{Conclusions and recommendations}

Main conclusion is that marketing will need to continue to respond to the demands of finance until the dominance of finance is challenged by developing an appropriate set of applied criteria in dialogue and decision-making, hence for data collection and attribution of returns. Finance may need to temper its demands and take greater responsibility in its interface management with marketing, developing a broader set of social and economic tools for making assessments. The pressure may come from the marketplace. ROMI offers a medium and long-term tool at business, business unit level to facilitate such a dialogue, which necessarily must commence with agreement to collect necessary data at CLV and programme levels of analysis. Thus, CLV and programme foci for ROMI data sets coupled with qualitative decision-making offer ways forward with constructive dialogue at the finance-marketing interface.

The main contribution to knowledge has been to examine ROMI for project businesses at a detailed level. It is perhaps surprising that this has been a neglected area of management and project management research. The main limitations arise from the exploratory nature of the study; however, repeated patterns of responses from the respondents lend credence to the findings.
Recommendations for further research therefore include a more extensive research into (i) marketing and ROMI application, and (ii) dialogue generation. We suggest further research into a review of the financial literature concerning other tools with a ROMI orientation, tools and protocols to facilitate dialogue at the marketing-finance interface. Finally, this research could also be replicated for specialist project businesses, including SMEs and entrepreneurial firms.

Recommendations for practice include the need for senior management to (i) facilitate a dialogue between marketing and finance, (ii) take a medium and long-term view in general and particularly for the application of ROMI, agreeing to collect and collate appropriate data, and (iii) take measure for finance to be more robust and consistent about the demands it makes.

\section{Conflict of interest}

There is no conflict of interest that could have inappropriately influenced, or be perceived to have influenced this research work.

\section{References}

Aaker, D., Jacobson, R., 1987. The role of risk in explaining differences in profitability. Acad. Manag. J. 30, 277-296.

Ambler, T., 2005. Maximizing profitability and return on investment: a short clarification on Reinartz, Thomas, and Kumar. J. Mark. 69, 153-154.

Anderson, E., Fornell, C., Mazvancheryl, S., 2004. Customer satisfaction and shareholder value. J. Mark. 68, 172-185

Artto, K., Davies, A., Kujala, J., Prencipe, A., 2011. The project business: analytical framework and research opportunities. In: Morris, P., Pinto, J., Söderlund, J. (Eds.), The Oxford Handbook of Project Management. Oxford University Press, Oxford, pp. 133-153.

Ballantyne, D., Varey, R., 2006. Introducing a dialogical orientation to the servicedominant logic of marketing. In: Lusch, R., Vargo, S. (Eds.), The ServiceDominant Logic of Marketing. M.E. Sharpe, New York, pp. 224-235.

Barney, J., 1991. Firm resources and sustained competitive advantage. J. Manag. 17, 99-120.

Batteau, P., Changeur, S., 2006. Performance marketing et performance financière: débats et enjeux. Atelier AFM de Recherche Appliquée la Performance du Marketing: de l'efficacité du mix au retour sur investissement, 26 April, Paris.

Borden, N., 1964. The concept of the marketing mix. J. Advert. Res. (June, 2-7).

Bourdreault, L., 2004. Le ROI est-il Roi? Propulsion, Propage. Bulletin Trimestriel, Autumn, Québec, Montreal.

Brady, T., Davies, A., 2004. Building project capabilities: from exploratory to exploitative learning. Organ. Stud. 25, 1601-1621

Capon, N., Farley, J., Hoenig, S., 1990. Determinants of financial performance: a meta-analysis. Manag. Sci. 36, 1143-1159

Chambers, M., Fitch, T., Keki, I., Smyth, H., 2009. Differences between customer experience and business development propositions: the case of a major contractor in the infrastructure market. Proceedings of the ARCOM 2009, 7th-9th September, Nottingham.

Cova, B., Hoskins, S., 1997. A twin track networking approach to project marketing. Eur. Manag. J. 15, 546-556.

Cova, B., Salle, R., 2011. Shaping project, building networks. In: Morris, P.W. G., Pinto, J., Söderlund, J. (Eds.), Oxford Handbook on the Management of Projects. Oxford University Press, Oxford, pp. 391-409.

Cova, B., Ghauri, P., Salle, R., 2002. Project Marketing: Beyond Competitive Bidding. John Wiley \& Sons, Chichester.

Davies, A., Brady, T., 2000. Organizational capabilities and learning in complex product systems: towards repeatable solutions. Res. Policy 29, 931-953.

Davies, A., Brady, T., Hobday, M., 2007. Organizing for solutions: systems seller vs. systems integrator. Ind. Mark. Manag. 36, 183-193. 
de Ruyter, K., Wetzels, M., 2000. The marketing-finance interface: a relational exchange perspective. J. Bus. Res. 50, 209-215.

Eggert, A., Ulaga, W., Hollman, S., 2006. Linking customer share to relationship performance: the customer perspective. Working Paper, ISBM Report 10-2006. Institute for the Study of Business Markets, The Pennsylvania State University, University Park, Pennsylvania.

Farris, P., Bendle, N., Pfeifer, P., Reibstein, D., 2006. Marketing Metrics: 50+ Metrics Every Executive Should Master. Wharton School Publishing, Pearson, New Jersey.

Ganesan, S., 2012. Handbook of Marketing and Finance. Edward Elgar, Cheltenham.

Garand, D., Nkonngolo-Bakenda, J.-M., 1996. L'approche biographique: une alternative utile aux recherches longitudinales en entrepreunariat et en gestion stratégique des PME. Groupe de recherche sur la PME et l'entrepreneurship (GREPME).

Griffith, J., 2004. The true value of EVA. J. Appl. Financ. 14, 25-29

Groleau, C., 2003. L'observation. In: Giordano, Y. (Ed.), Conduire un Projet de Recherche: une perspective qualitative. EMS, pp. 212-244.

Grönroos, C., 2000. Service Management and Marketing. John Wiley and Sons, London.

Gruneberg, S., Ive, G., 2000. The Economics of the Modern Construction Firm. Macmillan, Basingstoke.

Gupta, S., Zeithaml, V., 2006. Customer metrics and their impact on financial performance. Mark. Sci. 25, 718-739.

Gupta, S., Harvey, C., Siddique, A., 2000. Conditional skewness in asset pricing tests. J. Financ. 55, 1263-1295.

Hadjikhani, A., 1996. Project marketing and the management of discontinuity. Int. Bus. Rev. 5, 319-336.

Handy, C., 1997. Understanding Organizations. Penguin, London.

Hogan, J., Lehmann, D., Merino, M., Srivastava, R., Thomas, J., Verhoef, P., 2002. Linking customer assets to financial performance. J. Serv. Res. 5, 26-38.

Hong, G., Sarkar, S., 2007. Equity systematic risk (beta) and its determinants. Contemp. Account. Res. 24, 423-466.

Jensen, M., Meckling, W., 1976. Theory of the firm: managerial behavior, agency costs and ownership structure. J. Financ. Econ. 3, 305-360.

Journé, B., 2005. Étudier le management de l'imprévu: méthode dynamique d'observation in situ. Financ. Contrôle Stratég. 8, 63-91.

Kahneman, D., Tversky, A., 2000. Prospect theory: an analysis of decision under risk. In: Kahneman, D., Tversky, A. (Eds.), Choices, Values, and Frames. Cambridge University Press, Cambridge, pp. 17-43.

Kimbrough, M., McAlister, L., 2009. Linking marketing actions to value creation and firm value: insights from accounting research. In: Srinivasan, Hanssens (Eds.), Commentaries and Rejoinder to Marketing and Firm Value: Metrics, Methods, Findings, and Future Directions. Journal of Marketing Research, 46, pp. 313-319.

Lay, P., Hewlin, T., Moore, G., 2009. In a downturn, provoke your customers. Harv. Bus. Rev. 87, 48-56.

Lecoeuvre, L., Patel, K., 2009. Project marketing implementation and its link with project management and project portfolio management. Commun. Int. Bus. Inf. Manag. Assoc. 10, 50-63.

Lecoeuvre-Soudain, L., Deshayes, P., 2006. From marketing to project management. Proj. Manag. J. 37, 103-112.

Lenskold, J., 2003. Marketing ROI, the Path to Campaign, Customer, and Corporate Profitability. American Marketing Association, McGraw-Hill, New York.

Lev, B., 2004. Sharpening the intangibles edge. Harv. Bus. Rev. 82, 108-116.

Lui, D., Markov, S., Tamayo, A., 2007. What makes a stock risky? Evidence from sell-side analysts' risk ratings. J. Account. Res. 45, 629-665.

Mac, L., 2007. Measures of marketing performance assessment in an unpredictable world: a review of current literature. 36th EMAC Conference, Reykjavik Iceland.

Manchanda, P., Wittink, D., Ching, A., Cleanthous, P., Ding, M., Dong, X., Leeflang, P., Misra, S., Mizik, N., Narayanan, S., Steerburgh, T., Wieringa, J., Wosinska, M., Xie, Y., 2005. Understanding firm, physician and consumer choice behavior in the pharmaceutical industry. Mark. Lett. 16, 293-308.

McCarthy, E., 1964. Basic Marketing: a Managerial Approach. Richard D Irwin Inc.
Miles, M., Huberman, A., 2003. Analyse des Données Qualitatives, 2ème édition. De Boeck Université, Paris.

Mizik, N., Jacobson, R., 2003. Trading off between value creation and value appropriation. J. Mark. 67, 63-76.

Möller, K., 2006. Role of competences in creating customer value: a valuecreation logic approach. Ind. Mark. Manag. 35, 913-924.

Narayanan, V., DeFillippi, R., 2012. The influence of strategic context on project management systems: a senior management perspective. In: Williams, T., Samset, K. (Eds.), Project Governance: Getting Investment Right. Palgrave Macmillan, Basingstoke, pp. 3-45.

Powell, G., 2002. ROMI, Return on Marketing Investment, Demand More from your Marketing and Sales Investments. RPI Press, Atlanta.

Pryke, S., 2012. Social Network Analysis in Construction. Wiley-Blackwell, Chichester.

Reinartz, W., Thomas, J.S., Kumar, V., 2005. Balancing acquisition and retention resources to maximize customer profitability. J. Mark. 69, 63-79.

Rust, R., Lemon, K., Zeithaml, V., 2004. Return on marketing: using customer equity to focus marketing strategy. J. Mark. 68, 109-127.

Skaates, M., Tikkanen, H., 2003. International project marketing: an introduction to the INPM approach. Int. J. Proj. Manag. 21, 503-510.

Skaates, M., Tikkanen, H., Lindblom, J., 2002. Relationships and project marketing success. J. Bus. Ind. Mark. 17, 389-406.

Skitmore, M., Smyth, H., 2007. Pricing construction work: a marketing viewpoint. Constr. Manag. Econ. 25, 619-630.

Smyth, H., 2000. Marketing and Selling Construction Services. Blackwell Science, Oxford.

Smyth, H., Fitch, T., 2009. Application of relationship marketing and management: a large contractor case study. Constr. Manag. Econ. 27, 339-410.

Srinivasan, S., Hanssens, D., 2009. Marketing and firm value: metrics, methods, findings, and future directions. J. Mark. Res. 46, 313-319.

Srivastava, R., Shervani, T., Fahey, L., 1998. Market-based assets and shareholder value. J. Mark. 62, 2-18.

Storbacka, K., Nenonen, S., 2009. Customer relationships and the heterogeneity of firm performance. J. Bus. Ind. Mark. 24, 360-372.

Tobin, J., 1969. A general equilibrium approach to monetary theory. J. Money Credit Bank. 1, 15-29.

Tuli, K., Bharadwaj, S., 2009. Customer satisfaction and stock returns risk. J. Mark. 73, 184-197.

Tuli, K., Mukherjee, A., Dekimpe, M., 2012. On the value relevance of retailer advertising spending and same-store sales growth. J. Retail. 88, 447-461.

Turner, J., 2008. The Handbook of Project-based Management: Leading Strategic Change in Organizations, 3rd edition. McGraw-Hill Professional, Maidenhead.

Vargo, S., Lusch, R., 2004. Evolving to a new dominant logic for marketing. J. Mark. 68, 1-17.

Warnier, V., Lecocq, X., Demil, B., 2004. Le business model: l'oublié de la stratégie. Proceedings XIIIème conference AIMS, Le Havre, France.

Webster, F., Malter, A., Ganesan, S., 2005. Benchmarking marketing capabilities for sustained competitive advantage. J. Mark. 69, 80-94.

Weick, K., 1995. Sensemaking in Organizations. Sage Publications, Thousand Oaks.

Weissbrich, D., Miller, K., Krohmer, H., 2007. The marketing-finance interface: an integrative conceptual framework and performance implications. 36th EMAC Conference, Reykjavik, Iceland.

Wernerfelt, B., 1984. A resource-based view of the firm. Strateg. Manag. J. 5, $171-180$.

Whitley, R., 2006. Project-based firms: new organizational form or variations on a theme? Ind. Corp. Chang. 15, 77-99.

Wierenga, B., 2011. Handbook of Marketing Decision Models. Springer, New York.

Winch, G., 2010. Managing Construction Projects, 2nd edition. WileyBlackwell, Chichester.

Yin, R., 2009. Case Study Research. Design and Methods, 4th edition. Sage Publications, Thousand Oaks.

Zeithaml, V., Bolton, R., Deighton, J., Keiningham, T., Lemon, K., Petersen, J., 2006. Forward-looking focus: can firms have adaptive foresight? J. Serv. Res. 9, 168-183. 